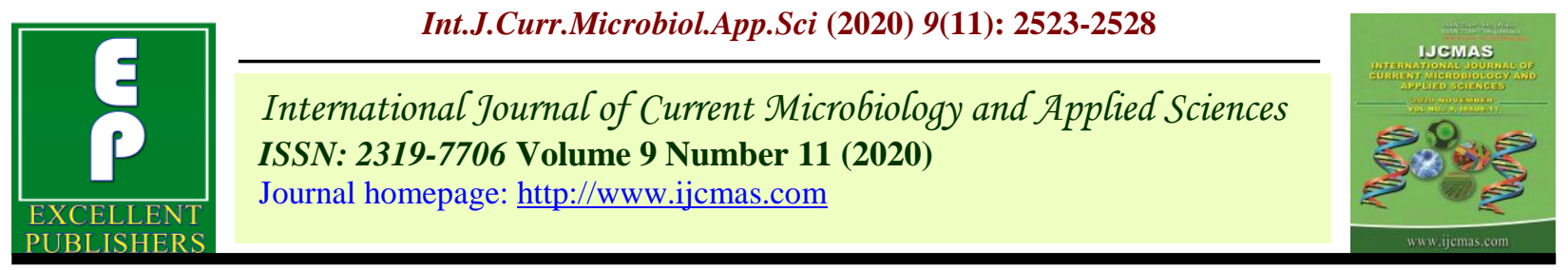

\title{
Effect of Cluster Fig Rhizosphere Consortia on Different Leafy Vegetables
}

\author{
Abhijeet V. Chavan*, K. G. Deshpande and Akhilesh K. Brahamanathkar \\ MGM College of Agricultural Biotechnology (CABT), Vasantrao Naik Marathwada Krishi \\ Vidyapeeth, Gandheli Aurangabad- 431003, Maharashtra, India \\ *Corresponding author
}

\section{A B S T R A C T}

\begin{tabular}{|l|}
\hline Key w o r d s \\
Unknown bacteria, \\
Biomix, \\
Rhizosphere \\
Consortia, \\
Morphological, \\
Biochemical and \\
genetic \\
identification \\
\hline Article Info \\
\hline $\begin{array}{l}\text { Accepted: } \\
\text { 20 October } 2020 \\
\text { Available Online: } \\
\text { 10 November } 2020\end{array}$ \\
\hline
\end{tabular}

The rhizosphere is part of the soil surrounding the plant roots or being influenced by the plant roots. The exudates released from roots make it a site for complex biochemical activity. Microorganisms make up one of the dynamic parts of this rhizosphere, and affect soil and plant growth by various means. However, our absolute dependency on chemical fertilizers and other agrochemicals, although enhancing crop production to the desired levels required to feed the growing world population, has not shown sufficient concern for sustainability, leading to two serious problems, ecological imbalance and resource limitation. An ecological disturbance has been created through polluting soil and water, putting toxic agrochemicals into the food chain, threatening human and animal health, and developing resistance in pests. On the other hand, resources are diminishing as vital nutrients like phosphorus are limited and very soon there will be an extreme shortage of these nutrients because excessive consumption will make them no longer available. Therefore, balancing plant needs through microbe-mediated sources is becoming an urgent priority. The rhizosphere microflora has many beneficial effects on plant growth and health promotion. The biomix is Prepared, Morphological, Biochemical and Genetic Identification is seen of Bacteria.

\section{Introduction}

Biomix is of completely organic origin and suitable of growing in potting soil and good for small plants. Biomix can be used in agriculture for various applications. Increases seed germination, promotes deeper rooting system. Biomix contains various types of bacteria which are beneficial to plants.

A biofertilizer (also bio-fertilizer) is a substance which contains living microorganisms which, when applied to seeds, plant surfaces, or soil, colonize the rhizosphere or the interior of the plant and promotes growth by increasing the supply or availability of primary nutrients to the host plant. Biofertilizers add nutrients through the natural processes of nitrogen fixation, solubilizing phosphorus, and stimulating plant growth through the synthesis of growthpromoting substances.

The microorganisms in biofertilizers restore the soil's natural nutrient cycle and build soil organic matter. Through the use of 
biofertilizers, healthy plants can be grown, while enhancing the sustainability and the health of the soil. Biofertilizers can be expected to reduce the use of synthetic fertilizers and pesticides, but they are not yet able to replace their use. Since they play several roles, a preferred scientific term for such beneficial bacteria is "plant-growth promoting rhizobacteria" (PGPR).

The growth and development of a plant is largely influenced by the soil environment, especially surrounding the roots. It is a microenvironment provided by the plant, where major contributors are the microbes. This region is specifically referred To as the 'rhizosphere,' and represents a realm of greater nutritional activity, Increased gas exchange, and enhanced release of root exudates, all of which collectively contribute to plant growth. As plants grow through soil, they release amino acids, sugars, and organic acids into soil that supply food for the microbes. In return, the microorganisms provide nutrients in available forms and other benefits to the plants.

All this activity makes the rhizosphere an extremely dynamic soil environment. It is thus important to understand the composition, ecology, and interactions of rhizosphere. The term rhizosphere was first defined by the German scientist Hiltner (1904), and is derived from the Greek word Rhiza meaning roots. It is an area near to plant roots inhabited by a diverse class of microflora influenced by the chemicals released from the plant roots. Today the rhizosphere is being redefined to include three distinct zones, viz., the endorhizosphere, the rhizoplane, and the ectorhizosphere.

The endorhizosphere includes root the cortex and the endodermis, which are occupied by endophytic bacteria. The zone directly adjacent to the root surface is called the rhizoplane, and includes the epidermis and mucilage; the ectorhizosphere extends from the rhizoplane out to the soil. The term endorhizosphere was useful to identify and illustrate the importance of those microorganisms that exist in the internal portion of the root; however, if the rhizosphere is soil based, then the term endorhizosphere may be appropriate as it identifies the region of the root and not the rhizosphere.

The ectorhizosphere is the actual portion of soil under the influence of plant roots. To avoid confusion between the endorhizosphere, rhizoplane, and ectorhizosphere, the terms root, rhizoplane, and rhizosphere, respectively, are used currently.

\section{Materials and Methods}

\section{Procedure}

\section{Collection of different soil samples}

Different soil samples were collected of different plants of Cluster fig. The soil samples were collected from Various Locations of Aurangabad District. 10 Soil samples were collected.

\section{Serial dilution}

Serial dilution is done of collected soil, (8no.test tube) each soils serial dilution process has been done.

\section{Isolation}

Isolation of bacteria is done of soil sample. Inoculated in Nutrient Broth Inoculation is done and then stored in Refrigerator for 48 hrs. Colony characterization is also done. Characters seen were shape, color, Margine, etc. 


\section{Gram staining}

Gram staining is done with gram staining kit, the loop full suspension was taken from culture obtained on Petri-plate after 48 hours of incubation. The results then seen under microscope, Rod shaped bacteria are seen and they were gram negative in nature. Further these colony Characterisation is done.

\section{Plate count for quality check}

Serial dilution is done of Nutrient broth of $100 \mathrm{ml}$, biomix is taken for these processes and then test tube is selected and inoculated in nutrient agar. After $24 \mathrm{hrs}$. colonies are counted in colony counter.

\section{Mass multiplication}

Mass multiplication is done of biomix in Nutrient Broth mixed it properly and stored for further application for field. Also added Glycerine for storing for long days.

\section{Field application}

4 vegetables crops were taken

1 Fenugreek

2 Corriander

3 Dilli leaves

4 Spinach

When Mass multiplication was going on sowing is also done, seed treatment is done to seeds by dissolving them into jaggery water and biomix mixture, water is given to crops as well, Drenching is done after 10 days of gap periods (Test are treated with Biomix and Control are Untreated).

\section{Observation}

The crops are observed every 10 days later, in perspective to height, no. of leaves or branches. Crops are divided into two parts Treated and Untreated i.e. test and control.

\section{Results and Discussion}

\section{Colony observation}

Whitish colony with little elevation was observed after 48 hours of incubation. It also has shiny appearance with uniform growth.

Its growth also determines the obtain strain is anaerobic in nature (Fig. 1).

\section{Gram's staining}

The obtained strain after gram staining was observed as Rod shaped, in form of chain and was gram negative color was pink when observed under microscope.

The following are the Average Observations of crop in these Biomix is applied on Test (Treated) and Control are (Untreated) (Table $1)$.

The purpose of the project was to see the effect of Rhizosphere consortia of cluster fig on different leafy vegetables. The Bacteria was isolated from soil and then isolation is done mass multiplication of biomix is done for drenching and to see results Crops were grown, According to the project observation were seen that the biomix treated plants was grown much faster and higher than the untreated vegetables plants. The growth was tremendously high in spinach crops, and Fenugreek as well. The Yield productivity biomix drenched plants was much more than untreated, this shows that the biomix of cluster fig helps to enhance the growth and productivity of vegetables. The biomix treated Dilli Leaves were also seen difference. Results were not much seen in Corriander, as some were not grown also, it concludes that the biomix doesn't effect on it (Fig. 2). 


\section{Table.1}

\begin{tabular}{|c|c|c|c|c|c|c|}
\hline \multicolumn{7}{|l|}{ 1) Fenugreek } \\
\hline \multicolumn{4}{|c|}{ Control (Untreated) } & \multicolumn{3}{|c|}{ Test (Treated) } \\
\hline Date & $\begin{array}{l}\text { Plant } \\
\text { no. }\end{array}$ & $\begin{array}{l}\text { Plant Height }(\mathrm{cm}) \\
\text { (Average) }\end{array}$ & $\begin{array}{l}\text { No. of Leaves } \\
\text { (Average) }\end{array}$ & $\begin{array}{l}\text { Plant } \\
\text { no. }\end{array}$ & $\begin{array}{l}\text { Plant Height }(\mathrm{cm}) \\
\text { (Average) }\end{array}$ & $\begin{array}{l}\text { No. of Leaves } \\
\text { (Average) }\end{array}$ \\
\hline $05 / 02 / 2020$ & 1 & 4.3 & 6 & 1 & 4.1 & 5 \\
\hline $15 / 02 / 2020$ & 2 & 5.0 & 7 & 2 & 4.6 & 6 \\
\hline $25 / 02 / 2020$ & 3 & 11.9 & 7 & 3 & 9.7 & 7 \\
\hline $05 / 03 / 2020$ & 4 & 13.3 & 9 & 4 & 12.5 & 8 \\
\hline $15 / 03 / 2020$ & 5 & 14.4 & 9 & 5 & 14.0 & 8 \\
\hline \multicolumn{7}{|l|}{ 2) Corriander } \\
\hline Date & $\begin{array}{l}\text { Plant } \\
\text { no. }\end{array}$ & $\begin{array}{l}\text { Plant Height }(\mathrm{cm}) \\
\text { (Average) }\end{array}$ & $\begin{array}{l}\text { No. of Branches } \\
\text { (Average) }\end{array}$ & $\begin{array}{l}\text { Plant } \\
\text { no. }\end{array}$ & $\begin{array}{l}\text { Plant Height }(\mathrm{cm}) \\
\text { (Average) }\end{array}$ & $\begin{array}{l}\text { No. of Branches } \\
\text { (Average) }\end{array}$ \\
\hline $05 / 02 / 2020$ & 1 & 2.1 & 3 & 1 & 1.6 & 2 \\
\hline $15 / 02 / 2020$ & 2 & 3.1 & 4 & 2 & 1.8 & 3 \\
\hline $25 / 02 / 2020$ & 3 & 4.2 & 5 & 3 & 3.0 & 3 \\
\hline $05 / 03 / 2020$ & 4 & 4.8 & 6 & 4 & 4.0 & 4 \\
\hline $15 / 03 / 2020$ & 5 & 10.3 & 7 & 5 & 7.1 & 4 \\
\hline \multicolumn{7}{|l|}{ 3) Dilli Leaves } \\
\hline Date & $\begin{array}{l}\text { Plant } \\
\text { no. }\end{array}$ & $\begin{array}{l}\text { Plant Height }(\mathrm{cm}) \\
\text { (Average) }\end{array}$ & $\begin{array}{l}\text { No. of Branches } \\
\text { (Average) }\end{array}$ & $\begin{array}{l}\text { Plant } \\
\text { no. }\end{array}$ & $\begin{array}{l}\text { Plant Height }(\mathrm{cm}) \\
\text { (Average) }\end{array}$ & $\begin{array}{l}\text { No. of Branches } \\
\text { (Average) }\end{array}$ \\
\hline $05 / 02 / 2020$ & 1 & 4.4 & 4 & 1 & 4.9 & 5 \\
\hline $15 / 02 / 2020$ & 2 & 5.4 & 4 & 2 & 5.5 & 5 \\
\hline $25 / 02 / 2020$ & 3 & 9.3 & 4 & 3 & 9.9 & 5 \\
\hline $05 / 03 / 2020$ & 4 & 9.7 & 4 & 4 & 10.7 & 5 \\
\hline $15 / 03 / 2020$ & 5 & 10.0 & 5 & 5 & 13.22 & 6 \\
\hline \multicolumn{7}{|l|}{ 4) Spinach } \\
\hline Date & $\begin{array}{l}\text { Plant } \\
\text { no. }\end{array}$ & $\begin{array}{l}\text { Plant Height }(\mathrm{cm}) \\
\text { (Average) }\end{array}$ & $\begin{array}{l}\text { No. of Leaves } \\
\text { (Average) }\end{array}$ & $\begin{array}{l}\text { Plant } \\
\text { no. }\end{array}$ & $\begin{array}{l}\text { Plant Height }(\mathrm{cm}) \\
\text { (Average) }\end{array}$ & $\begin{array}{l}\text { No. of Leaves } \\
\text { (Average) }\end{array}$ \\
\hline $05 / 02 / 2020$ & 1 & 4.5 & 4 & 1 & 3.4 & 4 \\
\hline $15 / 02 / 2020$ & 2 & 5.2 & 5 & 2 & 6.2 & 5 \\
\hline $25 / 02 / 2020$ & 3 & 11.7 & 5 & 3 & 13.7 & 6 \\
\hline $05 / 03 / 2020$ & 4 & 13.0 & 5 & 4 & 20.3 & 7 \\
\hline $15 / 03 / 2020$ & 5 & 18.8 & 6 & 5 & 22.5 & 7 \\
\hline
\end{tabular}


Plate count for quality check

\begin{tabular}{|l|c|}
\hline No. of Dilution & No. of Colonies \\
\hline Dilution 1 & 250 \\
\hline Dilution2 & 151 \\
\hline Dilution3 & 92 \\
\hline Dilution4 & 48 \\
\hline Dilution5 & 33 \\
\hline Dilution6 & 23 \\
\hline Dilution7 & 35 \\
\hline Dilution8 & 110 \\
\hline Dilution9 & 71 \\
\hline Dilution 10 & 22 \\
\hline
\end{tabular}

Fig.1 Colony observation
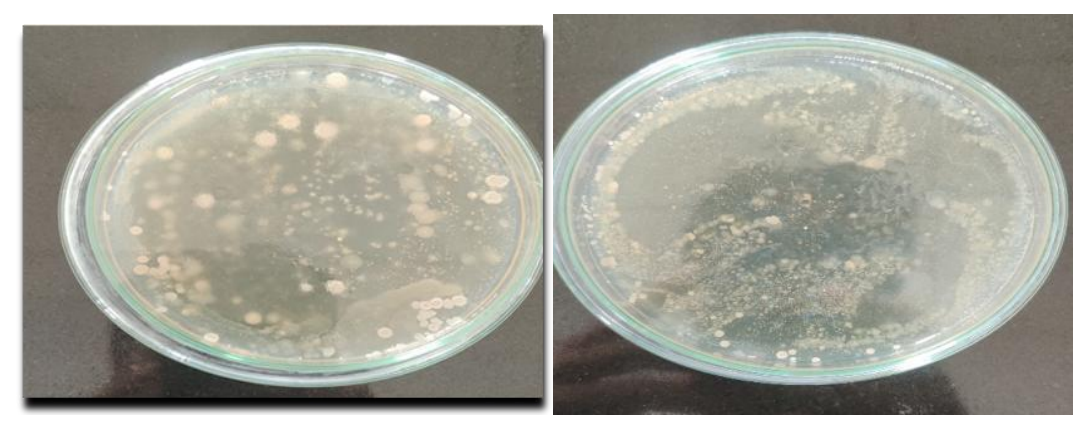

Fig.2 Observations - the biometric observations are taken after 10days' time period gaps
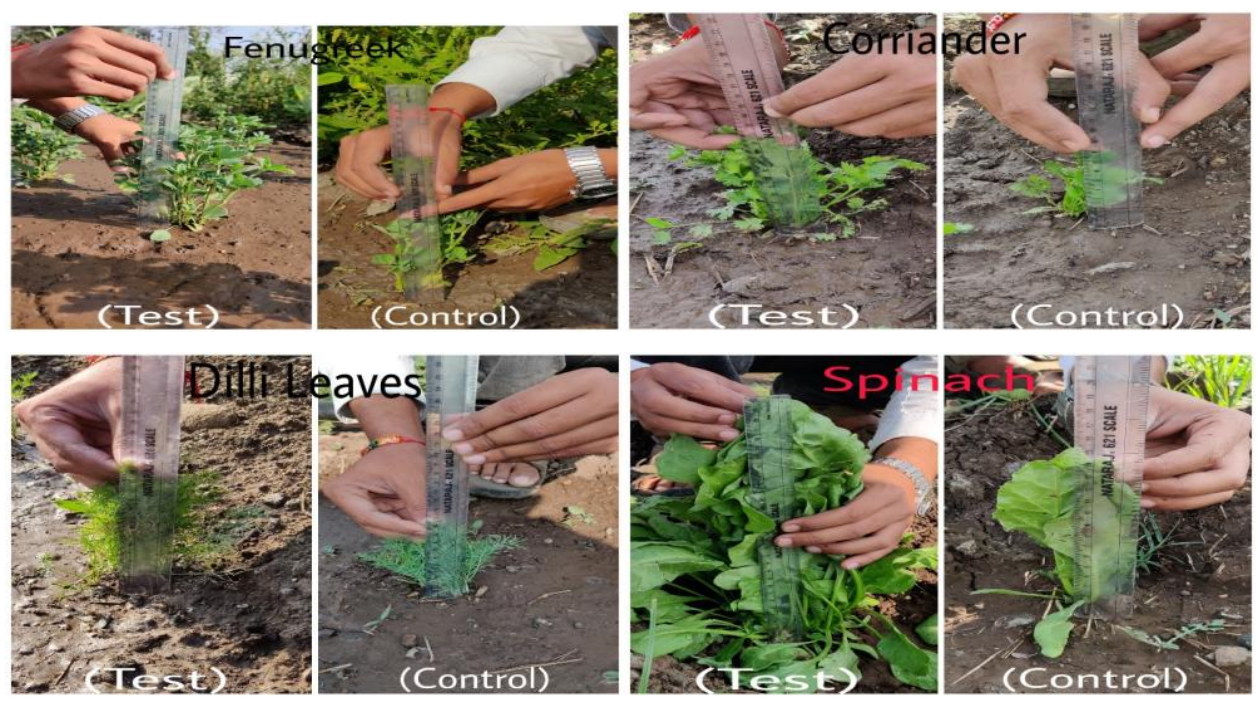

Sowing was done on $-21 / 01 / 2020$ 
Future perspective the isolated organism from cluster fig rhizosphere which showed excellent enhancement activity will be further assed for its Morphological, Biochemical, and Genetic identification.

\section{Acknowledgement}

The author acknowledges to his guide Prof. K $\mathrm{G}$ Deshpande Department of Microbial and Environmental Biotechnology, Dr. N R Chavan and all faculty members of MGM College of Agricultural Biotechnology for their support and cooperation during my research work.

\section{References}

Ahemad M, Kibret M (2014) Mechanisms and applications of plant growth promoting rhizobacteria: current perspective. JKSUS 26:1-20. 2013.05.00

Alami Y, Achouak W, Marol C, Heulin T (2000) Rhizosphere soil aggregation and plant growth promotion of spinach by an exopolysaccharide producing Rhizobium sp. Strain isolated from spinach roots.

Blom-Zandstra, M., (1989). Nitrate accumulation in vegetables and its relationship to quality. Annual Applied Biology. 115: 553-561

Borch, K., Bouma, T.J., Lynch, J.P., \& Brown, K.M., (1999). Ethylene: a regulator of root architectural responses to soil phosphorus availability. Plant, Cell and Environment

Cieslik, E., Greda, A., and Adamus, W., (2006). Contents of nitrogen in fruit and vegetables. Food Chemistry. 94: 135-142.

Collins, M., and McCoy, J.E., (1997). Chicory production, forage quality, and response to nitrogen fertilization. Agronomy Journal. 89: 232-238.

Dayamani K.J. (2010) Formulation and determination of effectiveness of liquid inoculants of plant growth promoting rhizobacteria. $\mathrm{PhD}$ thesis, University of Agricultural Sciences, Bengaluru, India.

Hayward, A. C. (1957). J. Gen. Microbiol. 16, 9-15.

Hiltner L (1904) uber neuere Erfahrungen und Probleme auf dem Gebiete der Bodenbakteriologie unter besonderer Berucksichtigung der Grundungung und Brache.59-78.

\section{How to cite this article:}

Abhijeet V. Chavan, K. G. Deshpande and Akhilesh K. Brahamanathkar. 2020. Effect of Cluster Fig Rhizosphere Consortia on Different Leafy Vegetables. Int.J.Curr.Microbiol.App.Sci. 9(11): 2523-2528. doi: https://doi.org/10.20546/ijcmas.2020.911.305 